\title{
TELAAH PEMIKIRAN EKONOMI MENURUT \\ IBNU QAYYIM (1292-1350 M / 691-751 H)
}

Oleh :

\author{
Ropi Marlina, SE., M.E.Sy.
}

Program Studi Akuntansi STIE Dr.Khez.Muttaqien. Email ropimarlina@gmail.com

\section{Juliana, S.Pd., M.E. Sy.}

Program Studi Akuntansi STIE Dr.Khez.Muttaqien dan Program Studi Ilmu Ekonomi dan

Keuangan Islam Universitas Pendidikan Indonesia. Email julian@upi.edu

\begin{abstract}
Asma Arisman Dewi
Mahasiswa Program Studi Ilmu Ekonomi dan Keuangan Islam Fakultas Pendidikan Ekonomi dan Bisnis Universitas. Email asma.arisman.dewi@student.upi.edu
\end{abstract}

\begin{abstract}
Abstrak
Dewasa ini, Barat seringkali menjadi poros atau kiblat pemikiran ekonomi dunia. Hampir bisa dipastikan bahwa ilmu-ilmu ekonomi yang diajarkan bangku-bangku sekolah dan perguruan tinggi adalah pemikiran ekonomi yang bermazhab pada kapitalis Barat. Padahal jauh sebelum pemikiran ekonomi dari Barat, Islam telah memiliki suatu konsep ekonomi yang di sampaikan oleh para pemikir-pemikir muslim yang merangkap pula sebagai ulama. Tulisan ini mencoba menguraikan pemikiran ekonomi menurut sudut pandang salah satu ulama yang hidup pada abad puncak kejayaan peradaban Islam, Ulama tersebut yaitu Ibnu Qayyim. Penulis mencoba menjelaskan apa dan bagaimana pemikiran ekonomi menurut Ibnu Qayyim al-Jawziyyah. Metode yang digunakan dalam penyempurnaan tulisan ini adalah, studi leteratur yang di ambil dari berbagai sumber baik itu beberapa buku karya Ibnu Qayyim sendiri, maupun buku dan jurnal-jurnal terkait yang di dalamnya memuat cara pandang Ibnu Qayyim berkaitan dengan ekonomi.

\section{PENDAHULUAN}

\section{Latar Belakang}

Konsep dasar ekonomi Islam bukanlah suatu hal yang baru dilakukan pada masa ini. Konsep atau pemikiran berkaitan dengan ekonomi telah lahir sejak ribuan tahun yang lalu bahkan jauh sebelum pemikir-pemikir ekonomi dari barat

bermunculan. Hal ini dibuktikan dengan beberapa fakta dan argument yang sangat kuat yang menunjukan ekonomi Islam sudah lebih dulu lahir dan diterapkan oleh masyarakat.

Lebih jauh, bahwa selama 14 abad perjalanan sejarah Islam, terdapat studi yang berkesinambungan tentang berbagai
\end{abstract}


isu ekonomi dalam pandangan Islam(A. Karim,2012:9).Pemikiran akan ekonomi tersebut telah diimplementasikan dimulai pada zaman Rasulullah, para khulafarasyidindan terus berkembang hingga saat ini. Meskipun perkembangan tersebut sempat mengalami masa stagnansi bahkan sering juga disebut sebagai masa tertutupnya pintu ijtihad yaitu di sekitar abad 9 sampai abad ke 14 Hijriyah, namun demikian sejarah telah mencatat bahwa hasil pemikiran mengenai ekonomi Islam pernah mencapai masa cemerlang yang ditandai dengan ditinggalkannya warisan intelektual yang sangat kaya yaitu pada sekitar abad ke-5 sampai abad ke-9 hijriyah.

Pada masa tersebut luas wilayah kekuasaan Islam sangat luas yang terbentang dari Maroko sampai Spanyol Barat bahkan hingga India di Timur. Kecemerlangan peradaban Islam tersebut mendorong lahirnya berbagai pusat-pusat kegiatan intelektual (Nur Chamid,2010: 217). Selain itu, di masa tersebut banyak terlahir tokoh-tokoh cendikiawan muslim yang memiliki kontribusi besar dalam perkembangan pemikiran ekonomi Islam, karya-karya mereka banyak dijadikan rujukan hingga kini, diantaranya : Al Ghazali (451-505 H / 1055-1111 M) , Nasirudin Tusi (485 H / 1093 M), Ibnu Taimiyah (661-728 H / 1263-1328 M), Abu Ishaq Al Shatibi (1388 M). Abdul Qadir Jaelani (1169 M), Ibnul Qayyim (1292 M), Ibnu Baja (1138 M), Ibnu Tufayl 1183 M), Ibnu Rusyd (1198 M), dan masih banyak lagi(Nur Chamid, 2010:218).

Dari sekian banyak pemikir-pemikir Islam pada fase petengahan tersebut, tedapat salah satu tokoh intelektual sekaligus ulama yang cikup terkenal pada zamannya. Ulama tersebut yaitu bernamaIbnu Qayyim. Ibnu merupakan salah satu tokoh yang hidup di zamannya, yang banyak melahirkan karya-karya. Ibnu Qayyim bukan tokoh yang fokus bergelut pada bidang ekonomi, namun pemikiran orisinalitas beliau tetap layak diakui eksistensinya. Oleh karena itu dalam artikel ini, penulis akan menjelaskan siapa dan bagaimana pemikiran Ibnu Qayyim berkaitan dengan ekonomi 


\section{KAJIAN PUSTAKA}

\section{Sejarah Singkat Ibnu Qayyim}

\section{Biografi Ibnu Qayyim}

Shams al-Din Abu 'Abdullah

Muhammad Ibnu Abu Bakar diketahui merupakan nama asli dari Ibnu Al Qayyim, dia dikenal dengan nama besar Ibnu Qayyim al-Jawziyyah, lahir di kota Damaskus yang merupakan ibu kota dan kota terbesar di Suriah, pada 29 Januari 1292 M (7 Safar 691 H). Dia lahir dari seorang ayah bernama Abu Bakar yang bekerja sebagai kepala sekolah pada Madrasah Al Jawziyyah(Ibn Rajab, 1956:242-252). Sebab itulah sang ayah mendapatkan gelar Qayyim AlJawziyyah(M. Iqbal, 2010:12). Dengan begitu arti dari nama Ibnu Qayyim alJawziyyah adalah anak dari ketua (kepala sekolah) al-Jawziyyah. Ayahnya adalah seseorang yang sangat menguasai ilmu fara'id (hukum waris) sehingga dari ayahnyalah dia pertama kali menimba ilmu dan memperdalam khususnya tentang hukum waris(Abu Zayd dan Ibn Qayyim alJawziyah:38-41).

Ibnu Qayyim memiliki keinginan yang begitu besar dalam menuntut ilmu. Tekad yang dimilikinya begitu luar biasa dalam menelaah serta mengkaji sejak masih muda, karena pada usia tujuh tahun Ibnu Qayyim telah memulai perjalanan ilmiahnya. Allah pun mengkarunianya bakat yang begitu melimpah yang kemudian ditopang dengan daya akal luas, daya hapal mengagumkan, pikiran cemerlang, dan energi yang sangat luar biasa. Karena itu tidak mengherankan jika dia turut berpartisipasi aktif dalam lingkaran ilmiah para syaikh (guru) dengan semangat yang tinggi serta jiwa energis untuk memuaskan obsesi dan rasa hausnya terhadap ilmu pengetahuan. Karena itu, semasa hidupnya dia telah menimba ilmu dari setiap ulama spesialis sehingga ia pun akhirnya menjadi ahli dalam ilmu-ilmu islam yang mempunyai andil besar dalam sejumlah disiplin ilmu pengetahuan(M. Iqbal, 2010:12). SebetulnyaIbnu Qayyim bukanlah ilmuwan Islam yang fokus pada permasalahan ekonomi, melainkan lebih banyak kepada Tafsir Al Quran, Sunah, dan permasalahan sosial dan politik, selain itu beliau juga merupakan ahli ilmu tasawuf.

Ibnu Qayyim hidup pada masa pemerintahan Sultan Nassir Muhammad bin Qalawun (1293-1341 M) yang mampu membangun pemerintahan yang relatif stabil dan memberikan perhatian yang lebih terhadap perbaikan kondisi ekonomi dan pendidikan di negeranya. Ibnu Qayyim melakukan redistribusi yang komprehensif terhadap pertanahan dan membuat reformasi dalam sistem perpajakan(Al- 
Maqrizi, 1933:90). Pada saat itu para ulama memiliki peran yang penting dan berpengaruh terhadap khalifah maupun juga masyarakat masa itu(Abdul Azim Islahi, 2012:2).

Salah satu guru terbesar Ibnu Qayyim adalah Ibnu Taimiyah, gurunya tersebut memiliki pengaruh yang sangat besar terhadap kematangan imu Ibnu Qayyim. Ibnu Qayyim menyertainya selama tujuh belas tahun, sejak dia menginjakan dirinya di damaskus hingga wafat, Ibnu Qayyim mengikuti dan membela pendapat gurunya dalam banyak kasus, itulah yang menyebabkan penyiksaan yang menyakitkan kepada mereka dari orang-orang taklid dan fanatik sehingga dirinya tidak bisa keluar dari

\section{Karya yang Dihasilkan Oleh Ibnu} Qayyim .

Selama hidupnya Ibnu Qayyim telah menghasilkan sejumlah puluhan kitab yang mencakup berbagai macam disiplin ilmu. Dalam sebuah referensi terhitung bahwa Ibnu Qayyim menghasilkan karya sekitar 90 kitab(M. Iqbal, 2010:26). Dari semua kitab hasil tulisannya, berikut beberapa karya besarnya, diantaranya :

Tahdzib Sunan Abi Daud, I'lam alMuwaqqi'in 'an Rabbil 'Alamin,Ighatsatul Lahfan fi Hukmi Thalaqil Ghadlban, penjara melainkan setelah kematian Ibnu Taimiyah(M. Iqbal, 2010:14).

Ibnu Qayyim merupakan seorang pemikir sosial yang menguraikan banyak hal tentang pandangan Ibnu Taimiyah dan menunjukkan suatu pandangan analisis dalam diskusi tentang masalah-masalah ekonomi(Ichsan Iqbal, 2012:8).Ibnu Qayyim meninggal pada malam kamis setelah adzan Isya, tanggal 26 September 1350 M (23 Rajab 751 H). Dia dishalatkan kesokan harinya setelah shalat dzuhur di mesjid Al-Umawi, kemudian di mesjid Jarah dan dimakamkan dipemakaman alBab ash-Shaghir dekat makam ibunya di Damaskus (Ibnul Qayyim AlJauziyah,2005:13).

Ighatsatul Lahfan fi Masha id asy-Syaithan, Bada I'ul Fawa'id, Amtsalul Qur'an, Buthlanul Kimiya' min Arba'ina wajhan, Bayan ad-Dalil 'ala istighna'ilMusabaqah 'an at-Tahlil, At-Tibyan fi Aqsamil Qur'an, At-Tahrir fi maa yahillu wa yahrum minal haris, Safrul Hijratain wa babus Sa'adatain, Aqdu Muhkamil Ahya' baina al-Kalimit Thayyib wal Amais Shalih alMarfu'ila Rabbis Sama',Syarhu Asma'il Kitabil Aziz, Zaadul Ma'ad fi Hadyi Kairul Ibad, Zaadul Musafirin ila Manazil asSu'ada' fi Hadyi Khatamil Anbiya', Jala'ul 
Afham fi dzkris shalati 'ala khairil Am, Ash-Shawa'iqul Mursalah 'Alal Jahmiyah wal Mu'aththilah, Asy-Syafiyatul Kafiyah fil Intishar lil firqatin Najiyah, Naqdul Manqul wal Muhakkil Mumayyiz bainal Mardud wal Maqbul, Hadi al-Arwah ila biladil Arrah, Nuz-hatul Musytaqin wa raudlatul Muhibbin, al-Jawabul Kafi Li man sa'ala 'anid Dawa is Syafi, Tuhfatul Wadud bi Ahkamil Maulud, Miftah daris Sa'adah, dan Al-Farqu bainal Khullah wal Mahabbah wa Munadhorotul Khalil li qaumihi(M. Iqbal, 2010:16).

\section{Pandangan Ibnu Qayyim tentang}

\section{Ekonomi Islam}

\section{Filosofi Ekonomi Islam}

\section{Homo Islamicus bukan Homo}

\section{Economicus}

Dalam paradigma ekonomi konvensional manusia seringdikatakan sebagai homo economicus yang digambarkan sebagai pribadi yang memiliki rasionalitas tak terbatas, dorongan bertindak yang murni untuk kepentingan pribadi, dan memiliki kendali yang sepenuhnya atas tindakan-tindakannya (http://david.susilo.blog.ugm.ac.id:2015).Be rbeda dengan pendapat Ibnu Qayyim, beliau menyorotidasar agama Islambahwa setiapmanusiabertanggung jawab di hadapanAllah(SWT) atas
Selanjutnya Madarijus Salikin baina manazil Iyyaka na'budu wa Iyyaka nasta'in, Ibnu al-Qayyim membahas pendapat yang berbeda tentang arti dan definisi Zuhd(Abdul Azim Islahi,2012:7).al-Turuq al-Hukmiyah, ia telah menyentuh pada isu-isu ekonomi misalnya, inspeksi pasar, pengendalian harga, monopoli, intervensi negara, dan sebagainya. dan masih banyak lagi kitabkitab serta karya-karya besar dia yang digemari oleh berbagai pihak.

perilakunyadanbahwa

Allah(SWT) adalahsumberarah danbimbingan(Ibnu Qayyim, 1978:15). Maka dari itu manusia akan menyadari tindakan-tindakan yang dilakukannya harus tetap didasarkan pada aturan-aturan yang Allah berikan dan tidak boleh semena-mena mementingkan kepentingan pribadi jika dalam pelaksanaannya dapat mendzalimi pihak lain, walaupun sebenarnya ia memiliki kendali yang penuh atas semua tindakan yang dilakukannya.

Ibnu

Qayyim

menekankanpandangan Islambahwa hidupiniadalah tesdanujian atau pengadilan. Tes danuji coba inidiberikanoleh Allah(SWT) melaluipemberiandan pengambilan kekayaandari suatu individu manusia. Sehingga kepemilikankekayaan 
bagi seseorangbukanlahbukti mengenai ada atau tidaknya nikmatAllah(Ibnu Qayyim,

\section{Keadilan}

Dalam banyak ayat, Allah memerintahkan manusia untuk berbuat adil. Dalam Islam adil didefinisikan sebagai laa tadzlimuna wa laa tudzlamun"tidak mendzalimi dan tidak didzalimi" (A. Karim, 2014:35).MenurutIbnu Qayyim (1978:14), keadilan( adl) adalahtujuan darisyariah. Selain ituSyariah tersebutterdiri dari keadilan, keberkahan dan kebijaksanaan.Suatu hal yang bertentangan dengan keadilan yang mengubah hal

\section{Nilai dan Dampaknya terhadap}

\section{Kehidupan Ekonomi}

Dalam pandangan Islam,manusia perlu untuk mengadopsi nilai-nilai seperti takut kepada Tuhan, kesalehan, kebajikan, kejujuran, kebenaran, dan untuk menjaga mereka dari kejahatan seperti kepalsuan, penipuan, serta korupsi.Menurut Ibnu Qayyim bahwa pada faktanya kejahatan seperti kebohongan, penipuan, kecemburuan, eksploitasi dan ketidak jujuran menciptakan kekacauan, kecurigaan, ketidakstabilan dan frustrasi dalam masyarakat akan berdampak pada penghambatan terhadap kemajuan ekonomi.
1978:194).

tersebut dari keberkahan dankesejahteraan dapatmenjadi sebuah kejahatan.

Hal itu juga berlaku bagi sebuah negara dalam menerapkan keadilandimana tidak boleh mendzalimi rakyatnya, hal itu berarti bahwa negara harus memastikan setiap rakyat tidak ada yang hidup menderita, negara harus memastikan bahwa rakyat di negara tersebut sudah terpenuhi kebutuhan pokonya berupa sandang, pangan dan papan serta menjamin kesehatan, pendidikan dan keamanan mereka terpenuhi.

Sebaliknya, tidak adanya kejahatan tersebut dan adanya nilai-nilai Islam menciptakan suasana kepercayaan dan keamanan dalam masyarakat yang akan mengningkatkan kerjasama dalam produksi dan stabilitas kondisi ekonomi. Nilai-nilai Islam tersebutbersifat positif dan diharapkan dapat meningkatkan produktifitas dan kesejahteraan umum bagi masyarakat (Abdul Azim Islahi, 2012:3). Begitupun halnya dengan kegiatan ekonomi, menurutnyasemua kegiatan ekonomi itu diperbolehkan kecuali yang secara khusus dilarang oleh Syariah(Ibnu Qayyim,(1955:344). 


\section{Kerjasama dan Divisi Perburuhan}

Ibnu Qayyim menekankan kerjasama ekonomi dan tanggung jawab sosial. Baginya, meskipun pekerjaan dibagi menjadi beberapa unit yang berbeda, manusia adalah seperti satu tubuh. Mereka harus bekerja sama dengan satu sama lain. Kerjasama ini akan memberikan manusia suatu karunia yang tidak akan pernah bisa mereka nikmati ketika bekerja secara independen. Ibnu Qayyim (1955:73) mempercayai adanya keragaman dan perbedaaan manusia sehingga mereka memerlukan kerja sama dan pembagian kerja.Dalam hal ini, nampak konsep tasawuf sangat kental dalam pemikiran Ibnu Qayyim tersebut.

Spesialisasi dalam ekonomi adalah pembagian tenaga kerja dimana individu atau perusahaan memusatkan usaha-usaha

\section{Milik Pribadi dan Intervensi Negara}

Ibnu Qayyim menganjurkan intervensi negara dalam kekayaan pribadi jika pemilik perorangan dalam menggunakan kekayaan mereka mempengaruhi kepentingan yang lebih besar dari masyarakat(Abdul Azim Islahi, 2012:5). Dalam hal ini dia menyimpulkan terutama dari hadits berikut : produktif mereka pada sebuah kegiatan atau sejumlah kegiatan-kegiatan yang terbatas. Dalam hal ini Ibnu Qayyim menyadari perbedaan dan keeragaman yang dimiliki tiap individu serta paham bahwa dalam sebuah pekerjaan setiap individu mempunyai bagiannya masing-masing maka dari itu bisa dipastikan bahwa Ibnu Qayyim juga memahami konsep spesialisasi kerja, namun yang ditekankan dalam pembahasanini adalah bukan mengenai spesialisasinya melainkan mengenai manfaat dari kerjasama, beliau mengatakan bahwa ketika kita bekerja sama untuk suatu hal tapi tetap dalam koridor masing-masing individu maka akan terdapat suatu karunia dari Allah yang tidak didapatkan ketika kita hanya bekerja secara independen, maka dari itu Ibnu Qayyim menganggap bahwa kerjasama itu penting.

Dari 'Abdullah bin 'Umar Radhiyallahu 'anhu, bahwa Rasulullah Shallallahu 'alaihi wa sallam bersabda:

“Barangsiapa memerdekakan persekutuannya dalam satu budak, dan ia mempunyai uang seharga budak itu, maka budak tersebut ditaksir dengan harga yang adil, dan tuan (yang membebaskan) itu 
memberikan uang kepada sekutu lainnya, kemudian budak itu dibebaskan. Apabila tidak (mempunyai uang), maka dimerdekakan dari budak itu apa yang telah ia merdekakan." Shahih Sunan Abi Dawud, Sunan at-Tirmidzi, dan Sunan Ibnu Majah.

\section{PandanganMengenai Kekayaan dan}

\section{Kemiskinan}

Ibnu Qayyim (1955:313-314) telah mencoba untuk membawa ajaran Islam secara seimbang berkaitan dengan kemiskinan dan kekayaan. Ia meneliti argumen mereka yang lebih memilih kemiskinan daripada kekayaan dan juga mereka yang lebih memilih kekayaandaripada kemiskinan. Menurutnya, kekayaan adalah lebih baik asalkan menyertai rasa syukur kepada Allah (SWT) dan pemenuhan seseorang kewajiban terhadap sesama manusia. Selain itu menurutnya keuntungan dari kekayaan adalah bahwa hal itu memungkinkan seseorang untuk melakukan segala macam perbuatan baik dengan mudah, misalnya, haji, jihad, pengeluaran wajib dan sukarela, pelepasan tawanan, hadiah, pembangunan masjid, jalan dan kanal, perkawinan dan sebagainya (Ibnu Qayyim, 1955:303).
Bisa disimpulkan dari atas bahwa negara memiliki hak untuk mengambil sesuatu dari tangan seseorang (swasta) setelah membayar kompensasi pada mereka jika hal tersebut dikarenakan adanya kepentingan yang lebih besar dari masyarakat yang memerlukan hal itu(Abdul Azim Islahi, 2012:5).

Berikut ini Ibnu Qayyim menganut pendapat gurunya IbnuTaimiyah yang mengatakan, "... Dari antara orang kaya dan orang miskin, makhluk yang paling disukai adalah orang yang paling takut kepada Tuhan dan yang unggul dalam perbuatan baik, jika kaya dan miskin adalah sama atas dasar kriteria ini, maka mereka sama dalam keadaan mereka masing-masing. "(Abdul Azim Islahi, 2012:6)

Sikap di atas adalah sepenuhnya sesuai dengan filosofi ekonomi Islam. Ibnu Qayyim mengatakan: Allah Yang Mahakuasa, adalah Pencipta keberlimpahan dan kekurangan sebagaimana Dialah yang menciptakan segala sesuatu. Kekayaan dan kemiskinan diciptakan oleh-Nya untuk menguji hamba Nya untuk yang lebih baik dalam perbuatan. Keduanya menjadi ajang pengujian untuk ketaatan atau ketidaktaatan, untuk pahala atau hukuman. 
Maka dari itu menurut Ibnu Qayyim (1978:162)kadang-kadang Allah menguji manusia dengan memberinya banyak

\section{Signifikansi Ekonomi Zakat}

Terkait masalah zakat, Ibnu Qayyim memberikan penjelasan yang cukup detail mengenai alasan dibalik tingkat zakat yang berbeda-beda dan periode pembayaran zakat yang 1 tahun. Ibnu Qayyim memaparkan bahwa tingkat zakat akan semakin rendah jika penggunaan tenaga kerja semakin intensif. Zakat untuk barang temuan adalah yang terbesar, yakni $20 \%$ karena untuk mendapatkan barang temuan tersebut relatif menggunakan tenaga kerja yang relatif lebih sedikit. Selanjutnya alasan sawah tadah hujan dikenakan tingkat zakat sebesar 10 persen, relatif lebih besar dibandingkan sawah irigasi sebesar 5 persen karena pada sawah irigasi dibutuhkan tenaga untuk membuat saluran irigasi dan menyalurkannya ke sawahsawah. Sehingga sawah irigasi lebih

\section{Bunga, Riba Fadhl dan Riba Nasi'ah}

Istilah riba secara bahasa berarti tambahan (ziyadah). Dengan kata lain, riba artinya tumbuh dan membesar. Sedangkan secara terminologi, riba dapat diartikan sebagai pengambilan tambahan dari harta kekayaan dan kadang-kadang oleh mempersempit dia rezekinya membutuhkan tenaga kerja dibandingkan dengan sawah tadah hujan (http://zonaekis.com:2015).

Selain itu Ibnu Qayyim juga menuliskan argument lainnya yang menyatakan bahwa beda tingkat pertumbuhan setiap barang yang mengakibatkan bedanya tingkat antar zakat. Terkait dengan periode pembayaran zakat, Al Qayyim berpandangan bahwa penggunaan periode 1 tahun adalah sangat tepat mengingat bahwa hasil dari investasikita pada umumnya baru akan terlihat setelah 1 tahun. Jika periode pembayaran zakat dibuat setiap bulan maka hal tersebut dapat menurunkan insentif para muzakki (pembayar zakat) untuk berproduksi lebih banyak lagi (http://zonaekis.com:2015).

pokok secara bathil, sehingga hukumnya diharamkan(Burhanuddin, 2010:39-40).

Secara umum, riba terbagi kedalam empat jenis, yakni riba qardh, jahiliyah, fadhl dan nasi'ah(Burhanuddin, 2010:41). Namun Ibnu Qayyim hanya membagi riba 
menjadi dua jenis, yakni riba Al Jali (terbuka) dan riba Al Khafi (samar). Riba Al Jali terjadi jika pemberi pinjaman mengenakan tambahan biaya atau bunga atas pinjamannya. Praktek seperti ini merupakan hal yang lazim dilakukan pada masa jahiliyah. Sedangkan Riba Al Khafi dibagi menjadi riba al-fadl (mengenakan jumlah tambahan ketika menukar barang yang sama) dan riba al-nasiyah (mengenakan jumlah tambahan ketika pembayaran tidak dilakukan pada saat yang sama dengan transaksi), (http://zonaekis.com:2015).Tetapi dari kedua jenis riba tersebut, kontribusi utamanya terletak pada riba al-fadhl dan riba al-nasi'ah yang dianggapnya sebagai bunga yang samar (al-riba al-khafi). Sehingga dua dari empat jenis riba yang diketahui saat ini merupakan sumbangan pemikiran dari Ibnu Qayyim.

Rasulullah telah menyebutkan tentang keenam jenis barang ribawi dalam sebuah hadits berikut, Diriwayatkan oleh Abu Said al-Khudri bahwa Rasulullah saw. Bersabda:

"Emas hendaklah dibayar dengan emas, perak dengan perak, gandum dengan

\section{Mekanisme Pasar dan Regulasi Harga}

Semenjak Ibnu Qayyim menjadi salah seorang murid yang sangat dekat gandum, tepung dengan tepung, kurma dengan kurma, garam dengan garam, bayaran harus dari tangan ke tangan (cash). Barangsiapa memberi tambahan atau meminta tambahan, sesungguhnya ia telah berurusan dengan riba. Penerima dan pemberi sama-sama bersalah. “ (HR Muslim no. 2971, dalam kitab alMasaqqah).

Selanjutnya, dari keenam jenis barang ribawi tersebut Ibnu Qayyim membaginya kedalam dua jenis yakni logam mulia dan bahan pangan. Diaberpandangan bahwa menukar logam mulia dalam bentuk perhiasan dengan logam mulia dalam bentuk uang dengan jumlah yang berbeda masih diperbolehkan mengingat ada biaya produksi dalam merubah logam mulia tersebut menjadi perhiasan, tetapi menukar logam mulia dalam bentuk koin dengan logam mulia dalam bentuk uang dengan jumlah yang berbeda tidak diperbolehkan. Satu kata kunci disini adalah bahwa uang yang selanjutnya dijadikan sebagai alat ukur nilai dari suatu barang haruslah bersifat stabil dan nilainya tidak dipengaruhi oleh faktorfaktor eksternal

lain.

dengan gurunya yakni Ibnu Taimiyah, ia mengikuti ide-ide gurunya dalam banyak kasus bahkan kata demi kata yang 
ditulispun sama persis, meskipun dalam beberapa kasus dia melakukan modifikasi dalam kalimat namun masih memiliki makna yang sama. Terutama, dalam kitabnya al-turuq al-Hukmiyah, dia telah menyentuh pada isu-isu ekonomi yang sama dengan yang dibahas oleh Ibnu Taimiyah dalam kitabnya al-Hisbah fi'lIslam, isu-isu ekonomi yang dibahas misalnya tentang, inspeksi pasar, pengendalian harga, monopoli, intervensi

\section{Isu Utama pada al-turuq al-Hukmiyah}

Setelah gurunya IbnuTaimiyah, Ibnu Qayyim (1953:244) menguraikan gagasan tentang harga pasar atau hargayang adil. Baginya, harga yang adil adalah harga normal yang terbentuk oleh permainan bebas kekuatan pasar, permintaan dan penawaran. Apabila harga tidak terbentuk secara alami (mengalami distorsi), maka ia menganjurkan fiksasi harga yang adil. Dalam hal ini, ia mengambil pertimbangan tidak hanya dari nilai subjektif suatu benda bagi penjual tetapi juga nilai subjektif dari objek bagi pembeli(Ibn al-Qayyim, 1953:258).

Dengan harga yang adil sebagai dasar, ia juga membahas kompensasi yang adil, upah yang adil, dan keuntungan yang adil. Tujuan utama dari harga yang adil dan isu-isu terkait lainnya adalah untuk menjaga negara, dan sebagainya(Abdul Azim Islahi, 2012:20).

Sejalan dengan IbnuTaimiyah, Ibnu Qayyim berpandangan bahwa harga harus dibentuk oleh keseimbangan supply dan demand yang terbentuk di pasar. Selain itu, Ibnu Qayyim juga memandang penting peran dari Al Hisbah, yakni sebuah lembaga untuk mengontrol, mengintervensi dan mengawasi kegiatan ekonomi (http://zonaekis.com:2015).

keadilan di antara anggota masyarakat dan untuk memberikan pedoman bagi pemerintah untuk melindungi masyarakat dari eksploitasi. Dia tidak membatasi dirinya untuk analisis harga yang adil dan mekanisme pasar. Dia mengemukakan pendapat kebijakan rinci kontrol harga untuk negara. Subjek kontrol harga telah sangat kontroversial di kalangan pemikir Muslim. Seperti Ibnu Taimiyah, posisi Ibnu Qayyim adalah antara dua ekstrem, larangan mutlak dan peraturan negara tanpa syarat harga. Dia tidak mendukung pengendalian harga ketika kekuatan pasar kompetitif yang diizinkan untuk bekerja secara bebas. Dia merekomendasikan pengendalian harga dalam kasus monopoli atau ketidaksempurnaan di pasar(Ibn alQayyim, 1953:253). 
Prinsip yang sama akan berlaku untuk tenaga kerja dan layanan lainnya.Dia berargumen bahwa jika minat masyarakat tidak dilayani dengan tidak adanya fiksasi harga, harga harus tetap untuk mereka tanpa

\section{Al-Hisbah}

Al-hisbah dapat didefinisikan sebagai lembaga yang mengontrol dan menggiring kepada yang baik (al-ma`ruf) dan mencegah dari yang buruk (al-munkar). Kontrol berkaitan dengan apa yang tidak jatuh di bawah otoritas eksekutif, gubernur, hakim atau pejabat publik tertentu lainnya.Yurisdiksinya tidak terbatas pada bidang ekonomi saja; mengangkat dan mengawasi pekerjaan sosial dan sipil dan memperhatikan moral dan spiritual mereka

\section{Pandangan Ekonomi Syariah Tentang} Waktu (Pembayaran dengan Kredit)

Ibnu Qayyim merupakan salah satu ilmuwan Islam yang mendukung pemberlakuan harga yang lebih tinggi untuk kasus pembayaran yang ditangguhkan. Jika seseorang memberikan barang pada saat ini dan menerima pembayarannya pada masa melakukan kerusakan pada siapa pun. Tapi ketika kebutuhan mereka terpenuhi dan kepentingan mereka dilayani tanpa fiksasi harga, seharusnya tidak dilakukan (Ibn alQayyim, 1953:264). jugamerupakan fungsi al-hisbah. Fungsi utama dari lembaga lembaga al-hisbah yang untuk memastikan pasokan dan penyediaan kebutuhan, untuk mengawasi industri, perdagangan dan jasa lainnya, untuk memeriksa berat dan ukuran serta standar produk, dan untuk mencegah distorsi seperti penimbunan, perjudian dan praktek riba dan banyak kejahatan ekonomi lainnya (Ibn alQayyim, 1953:244).Sehingga melalui lembaga ininegaradapat mengontrol, campur tangan dan mengawasi berbagai kegiatan ekonomimasyarakat (Abdul Azim Islahi, 2012:21).

yang akan datang maka diperbolehkan baginya untuk menerima tingkat harga yang lebih tinggi karena adanya opportunity cost yang muncul. Namun hal ini hanya berlaku untuk komoditi selain daripada logam mulia dan bahan pangan(http://zonaekis.com:2015). 


\section{Pandangan Ibnu Qayyim tentang Uang}

Ibnu Qayyim mengidentifikasi dua fungsi utama uang, yaitu sebagai media pertukaran dan standar nilai. Menurut

\section{KESIMPULAN}

Ibnu Qayyim al-Jawziyyah, lahir di kota Damaskus yang merupakan ibu kota dan kota terbesar di Suriah, pada 29 Januari 1292 M (7 Safar 691 H). Dia lahir dari seorang ayah bernama Abu Bakar yang bekerja sebagai kepala sekolah pada Madrasah Al Jawziyyah. Begitu besar dalam menimba ilmu, sehingga dia mampu menjadi ahli dalam ilmu-ilmu islam dan mempunyai andil besar dalam sejumlah disiplin ilmu pengetahuan. Dia meninggal pada tanggal 26 September 1350 M (23 Rajab $751 \mathrm{H})$.

Beberapa diantara karya dia adalah Madarijus Salikin baina manazil Iyyaka na'budu wa Iyyaka nasta'in, Ibnu alQayyim membahas pendapat yang berbeda pandangannya penyimpangan terhadap kedua fungsi uang ini bisa terjadi ketika orang menghendaki uang untuk keperluan uang itu sendiri (Karnaen, 2006:66).

tentang arti dan definisi zuhd.al-Turuq alHukmiyah, ia telah menyentuh pada isu-isu ekonomi misalnya, inspeksi pasar, pengendalian harga, monopoli, negaraintervensi, dan sebagainya. dan masih banyak lagi kitab-kitab serta karyakarya besar dia yang digemari oleh berbagai pihak.

Dalam hal ekonomi, pemikiran ekonomi Ibnu Qayyim bisa dibagi kedalam tujuh kategori besar, yaitu :1) Pandangannya tentang filosofi ekonomi Islam, 2)Mengenai kekayaan dan kemiskinan, 3) Signifikansi ekonomi zakat, 4) Bunga, riba Fadhl dan riba Nasi'ah, 5) Mekanisme pasar dan regulasi pasar, 6) Pandangan Ekonomi Syariah Tentang Waktu, 7) Pandangan Ibnu Qayyim tentang Uang. 


\section{DAFTAR PUSTAKA}

Alam,M. Iqbal (2010). Konsep Ruh dalam Perspektif Islam : (Pemahaman Hadis tentang Ruh dalam Kitab Ar-Ruh Karya Ibnul Qayyim Al Jawziyah). (Skripsi). Fakultas Ushuluddin dan Filsafat, UIN Syarif Hidayatullah.

Al-Jauziyah, Ibnul Qayyim.(2005). Ar-Ruh. Beirut : Daarul Fiqr.

al-Maqrizi. (1933)al-Khitat.Cairo: Mu'assasah al-Halabi. Vol.1, hlm.90.

Chamid, Nur. (2010). Jejak Langkah Sejarah Pemikiran Ekonomi Islam. Yogyakarta : Pustaka Pelajar

Iqbal, Ichsan. (2012). Pemikiran Ekonomi Islam Tentang Uang, Harga dan Pasar. Syariah STAIN Pontianak.2 (1),

Islahi, Abdul Azim. (2012). Economic Thought of Ibnu Qayyim (1292-1350). International Centre for Research in Islamic Economics, King Abdul Aziz University, Jeddah, Saudi Arabia.

Karim, Adiwarman Azwar. (2012). Sejarah Pemikiran Ekonomi Islam. Jakarta : PT Raja Grafindo Persada. Edisi Ketiga.
(2014). Ekonomi Mikro Islami.Jakarta : Rajawali Pers. Edisi Kelima Karnaen, A.Perwataatmadja. (2006) Diktat Kuliah Sejarah Pemikiran Ekonomi Islam. Qayyim,Ibnu. (1953) al-Turuq alHukmiyah, Cairo: al-Sunnah alMuhammadiyah.

(1955) I Iam al-Muwaqqi in. Cairo: Maktabah al-Sa'adah. Vol. 1. Hlm. 344. . Zad al-Ma`ad, Cairo: al-Matba`ah al-Misriyah, n.d. Vol. 3, Hlm. 15.

Qayyim,Ibnu. (1978). 'Uddat al-Sabirin. Beirut: Dar al-Afaq al-Jadidah.Hlm. 194.

Miftah Dar al-Sa`adah. Beirut: Dar al-Kutub al-Ilmiyyah, Part 2, Hlm.73.

Rajab, Ibn (1956)Kitab al-Dhayl ‘ala Tabaqat al-Hanabilah, Cairo: Matba'ah alSunan al- Muhammadiyah.

S., Burhanuddin. (2010). Aspek Hukum Lembaga Keuangan Syariah. Yogyakarta : Graha Ilmu.

Irawan, Tony. (2012). Pemikiran ekonomi Ibnu Al-Qayyim. [Online]. Tersedia di : http://zonaekis.com/pemikiran- 
ekonomi-ibnu-al-qayyim/ [Diakses 13 Juli 2015]

Nugroho, David Susilo. (2014).

Mempertanyakan Gagasan Homo

Economicus: Psychological

Review. [Online]. Tersedia di http://david.susilo.blog.ugm.ac.id/in dex.php/mempertanyakan-gagasan-

homo-oeconomicus/ [Diakses 16

Agustus 2015]

Zakariya, R. A. (2013). Biografi Ibnul Qayyim al-Jauziyah. [Online]. Tersedia di : http://kisahmuslim.com/biografi-

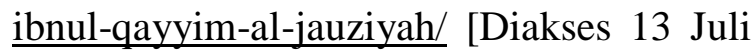
2015] 